\title{
Effect of limestone and dolomite tailings' particle size on potentially toxic elements adsorption
}

https://doi.org/10.1515/geo-2018-0058

Received Jan 15, 2018; accepted Oct 16, 2018

\begin{abstract}
The aim of the study is the investigation of potentially toxic elements adsorption on limestone, dolomite and marble particles of different size. As parameters, rock particle size, solution concentration, contact time and presence of other elements in the solution have been investigated. Four fractions with different particle size $(-4 \mathrm{~mm}$ $+1 \mathrm{~mm},-1 \mathrm{~mm}+315 \mu \mathrm{m},-315 \mu \mathrm{m}+90 \mu \mathrm{m},<90 \mu \mathrm{m})$ have been studied. Batch experiments have been carried out at 20, 60, 120 min from monoelement and competitive $\mathrm{Cd}$, $\mathrm{Cu}, \mathrm{Pb}, \mathrm{Zn}$ solutions at concentrations $5,100,500 \mathrm{mg} / \mathrm{L}$, whereas fixed bed conditions have also been applied. In lower concentrations, adsorption reaches equilibrium after $60 \mathrm{~min} .15 \%$ difference in $\mathrm{Pb}$ adsorption and $15-30 \%$ in $\mathrm{Zn}$ adsorption has been observed depending on particle size. However, according to Taguchi method particle size has not proven a determinative parameter, so as to make grinding and/or sieving necessary for their further utilisation. $\mathrm{Cd}$ and $\mathrm{Zn}$ adsorption from a competitive solution is lower, whereas $\mathrm{Cu}$ and $\mathrm{Pb}$ adsorption is similar. Adsorption capacity of materials rises up to $0.03 \mathrm{mg} \mathrm{Cd} / \mathrm{g}, 0.60$ $\mathrm{mg} \mathrm{Cu} / \mathrm{g}, 0.03 \mathrm{mg} \mathrm{Pb} / \mathrm{g}, 0.60 \mathrm{mg} \mathrm{Zn/g}$. In fixed bed conditions more than $93 \%$ element is adsorbed, of which only $4 \%$ is leached.
\end{abstract}

Keywords: Limestone, dolomite, marble, potentially toxic element, adsorption capacity, particle size

\section{Introduction}

The rapid development of industries such as mining, specifically electroplating, metal-finishing, paint and

\footnotetext{
*Corresponding Author: Sofia Farmaki: National Technical University of Athens, School of Chemical Engineering, Laboratory of Inorganic and Analytical Chemistry, Athens, Greece;

Email: sofiafarm@geol.uoa.gr

Eleni Vorrisi, Olga K. Karakasi, Angeliki Moutsatsou: National Technical University of Athens, School of Chemical Engineering, Laboratory of Inorganic and Analytical Chemistry, Athens, Greece
}

plastic manufacturing, without effective control has resulted in a large accumulation of potentially toxic elements like heavy metals in soils, which are generally immutable, not degradable and persistent. In this field, the chemical behaviour of the mineral surfaces in aquatic environments and the elucidation of the mineral-water interface interactions have forced researchers on investigating the mechanisms of metal adsorption on carbonate minerals. Adsorption experiments on calcite or dolomite have taken place mainly from monoelement solutions in batch conditions [1]. The effect of $\mathrm{pH}$ of the materials is also an important property affecting their retention capacity of cations. $\mathrm{H}^{+}$adsorption at the mineral-water interface modifies the surface charge, the surface potential and the distribution of ions in the solution surrounding the solid by formation of complexes.

A wide range of divalent metallic cations, including common diagenetic tracers $\left(e . g . \mathrm{Mg}^{2+}, \mathrm{Mn}^{2+}, \mathrm{Sr}^{2+}\right)$ and important environmental contaminants (e.g. $\mathrm{Ni}^{2+}, \mathrm{Zn}^{2+}$, $\left.\mathrm{Co}^{2+}, \mathrm{Cd}^{2+}, \mathrm{Pb}^{2+}\right)$, can potentially substitute for $\mathrm{Ca}^{2+}$ ions in the calcite structure [2]. Elements substitutions, vacancies, structural defects etc. result active surfaces allowing ion-exchange, surface precipitation and co-precipitation of ions. This property makes carbonate minerals attractive sorbent materials for potentially toxic element removal from waste streams.

Adsorption on calcitic minerals from monoelement solutions of $\mathrm{Cd}, \mathrm{Co}, \mathrm{Cr}, \mathrm{Cu}, \mathrm{Ni}, \mathrm{Pb}$ and $\mathrm{Zn}$ has been investigated with encouraging results. In particular, the sorption selectivity of calcite with extra fine particle size $(<9 \mu \mathrm{m})$, has proven to follow the sequence $\mathrm{Cd}>\mathrm{Zn} \geq$ $\mathrm{Mn}>\mathrm{Co}>\mathrm{Ni}>>\mathrm{Ba}=\mathrm{Sr}[3] . \mathrm{Pb}$ adsorption on calcite with particle size, varying from 2 to $200 \mu \mathrm{m}$, has also proven effective, either by being strongly adsorbed on calcite surface or by precipitating as cerrusite, hydrocerrusite, plumbonacrite or hydroxy lead compounds [4-6]. In case of $\mathrm{Zn}$ a heterogeneous nucleation of $\mathrm{Zn}$-bearing precipitate on calcite surface has been observed [7]. Limestone with very coarse particle size $(2.36-4.75 \mathrm{~mm})$ has also been investigated for beneficial removal of $\mathrm{Cd}, \mathrm{Pb}, \mathrm{Zn}, \mathrm{Ni}$, $\mathrm{Cu}, \mathrm{Cr}$ from monoelement solutions exceeding 90\% [8]. $\mathrm{Cd}$ adsorption and solid-state diffusion into the crystal 
takes place on single-crystal calcite cleavage fragments (8$10 \mathrm{~mm}^{2}$ by $2-2.5 \mathrm{~mm}$ thick) [9], whereas $\mathrm{Cd}^{2+}$ uptake by calcite cleavage faces has proven more rapid than $\mathrm{Pb}^{2+}$ uptake [10]. Furthermore, $\mathrm{Cd}$ adsorption by direct precipitation as cadmium carbonate on limestone with coarse particle size $(1.4-2.0 \mathrm{~mm})$ has been observed in a two column siderite/limestone reactor [11]. $\mathrm{Cd}, \mathrm{Cr}, \mathrm{Zn}$ adsorption on calcite with finer particle size $(0.2-1.0 \mathrm{~mm})$ in both batch and fixed bed conditions is achieved respectively through $\mathrm{Cd}$ exchange with $\mathrm{Ca}$, precipitation of $\mathrm{Zn}$ as hydrozincite $\mathrm{Zn}_{5}(\mathrm{OH})_{6}\left(\mathrm{CO}_{3}\right)_{2}$ and precipitation of $\mathrm{Cr}$ as anoxide hydrocarbonate coating [12].

Dolomite powder has been investigated for $\mathrm{Cd}$ and $\mathrm{Pb}$ adsorption from aqueous medium with encouraging results at $\mathrm{pH} 5$ as an optimum value [13]. $\mathrm{Cu}$ and $\mathrm{Pb}$ adsorption from monoelement solutions on dolomite with fine particle size rising up to $200 \mu \mathrm{m}$ exceeding $85 \%$ has been achieved through surface complexation and ion exchange $[14,15]$. $\mathrm{Co}, \mathrm{Cd}, \mathrm{Pb}, \mathrm{Cr}$ adsorption on polished dolomitic marble slices $\left(1 \times 1 \mathrm{~cm}^{2}\right)$ has been achieved by formation of a Co-bearing film on its surface, adsorption and solid-state diffusion of $\mathrm{Cd}^{2+}$, extended overgrowth of crystalline $\mathrm{Pb}^{2+}$ carbonates and massive surface precipitation of amorphous $\mathrm{Cr}^{3+}$ hydroxide/oxyhydroxide [16] .

As it results from the aforementioned references, particle size has not been examined yet as a specific parameter, for adsorption from a liquid waste burdened with a number of potentially toxic elements, on carbonate minerals. Furthermore, adsorption from competitive solutions is still a field where bibliography also remains poor.

Reserves of carbonate rocks, appropriate as inert material, are abundant in Greece with 230 quarries in operation. Great quantities of tailings and by-products deriving from the extraction which is an economically important and widespread activity remain unexploited, since they are considered inappropriate due to their physical and chemical characteristics, referring to shape, purity, etc. [17]. In combination with great quantities, resulting from cutting, smoothing and polishing of marble, they may cause environmental problems.

The present study aims at investigating the effect of rocks' particle size on their behaviour in potentially toxic element adsorption and the retention mechanisms, so as to estimate, whether grinding and/or sieving is necessary for their further utilisation as base material of a landfill. To this direction, Taguchi method has also been applied, in order to compare the effect of particle size on potentially toxic element adsorption with other parameters, including solution concentration and contact time. The adsorption process has been studied from both monoelement and competitive solutions, so as to simulate real waste streams in case the rocks are used for such an application. The nature of the adsorption isotherms has been also evaluated. Finally, the element retention capacity of the mineral tailings has been estimated by leaching tests.

\section{Materials and Methods}

\subsection{Samples}

Samples of limestone and dolomite have been excavated from different depths and supplied by the company TITAN Group dealing with production, transport and trading of ready-mixed concrete and quarry products in Greece. On the other hand, samples of limestone marble and dolomitic marble have been supplied by quarries in Penteli of Attiki and Volakas of Drama in Greece respectively, resulting from both cutting and smoothing the exploited rock and remains of the exploited rock. It must be noted that these materials cannot be used or recycled by the specific companies, due to their inappropriate particle size.

In order to investigate the effect of sample particle size on potentially toxic element adsorption, which is a critical parameter so as to estimate, whether grinding and/or sieving of the mineral tailings is necessary for their further utilisation, samples have been crashed and separated into their grain fractions by mechanical screening. The standard DIN 4188-1:1977-10 has been applied, including material division in four quadrants and cross selection of two quadrants constituting the sample, and subsequently sample dry sieving. Each sample has been divided into four fractions with particle sizes $-4 \mathrm{~mm}+1 \mathrm{~mm},-1 \mathrm{~mm}+$ $315 \mu \mathrm{m},-315 \mu \mathrm{m}+90 \mu \mathrm{m}$ and $<90 \mu \mathrm{m}$ respectively. The particle size distribution of the samples is shown in Table 1, expressed as \% retained material on each sieve.

For the qualitative element analysis X-Ray Fluorescence (XRF, ARL ADVANT XP) has been applied and samples have been prepared as fused beads. All the elements have been determined by Inductively Coupled Plasma Atomic Emission Spectroscopy (ICP-MS, Perkin ElmerELAN 6100), except $\mathrm{Cd}, \mathrm{Cr}, \mathrm{Cu}, \mathrm{Ni}$, whose quantitative analysis has been also certified by Flame Atomic Absorption Spectrometry (AAS, VARIAN AA240FS) and samples have been digested with $\mathrm{HCl}$, whereas lithium tetraborate fusion has been applied for any remaining material. The mineralogical composition of the samples has been determined by X-Ray Diffraction (XRD, Siemens D-500) with further analysis in a petrographic microscope (LEICA DMLP).

In order to investigate the adsorption mechanisms, further parameters have also been measured: $\mathrm{pH}$ accord- 
Table 1: Particle size distribution of the samples.

\begin{tabular}{ccccc}
\hline particle size & \multicolumn{4}{c}{$\%$ retained } \\
\cline { 2 - 5 } & limestone & limestone marble & dolomite & dolomitic marble \\
\hline$+4 \mathrm{~mm}$ & 15.30 & 17.14 & 33.38 & 6.38 \\
$-4 \mathrm{~mm}+1 \mathrm{~mm}$ & 54.73 & 43.45 & 30.80 & 12.68 \\
$-1 \mathrm{~mm}+315 \mu \mathrm{m}$ & 15.23 & 15.04 & 18.79 & 8.41 \\
$-315 \mu \mathrm{m}+90 \mu \mathrm{m}$ & 4.76 & 14.98 & 10.08 & 61.13 \\
$-90 \mu \mathrm{m}$ & 9.99 & 9.39 & 6.94 & 11.39 \\
\hline
\end{tabular}

ing to ISO 6588-1:2012, porosity and specific surface area by $\mathrm{N}_{2}$-adsorption (NOVA-2200 Ver. 6.11) and cation-exchange capacity (CEC) according to EPA 9081 [18], based on mixing the sample with an excess of sodium acetate solution, resulting in an exchange of the added sodium cations for the matrix cations, being then determined.

\subsection{Methods}

\section{Sorption studies}

Potentially toxic element sorption has been studied as a function of sample particle size, solution concentration and contact time, including experiments in both batch and fixed bed conditions in case of using such materials as base of a landfill.

Monoelement solutions containing $\mathrm{Cd}, \mathrm{Pb}, \mathrm{Cu}$ and $\mathrm{Zn}$ at 5, 100 and $500 \mathrm{mg} / \mathrm{L}$ have been prepared from Fluka analytical standard solutions of their nitrate salts. The $\mathrm{pH}$ of the solutions has been adjusted to 5 by adding $\mathrm{HNO}_{3}$ or $\mathrm{NaOH}$, as performed experiments have shown precipitation $37-98 \%$ of the aforementioned ions in a competitive solution by increasing $\mathrm{pH}$ from 5 to 8 [19].

The batch experiments have been carried out for all the aforementioned material fractions three times and the result is the mean value. In particular, $5 \mathrm{~g}$ of sorbent have been added to $30 \mathrm{~mL}$ of each solution in a $250 \mathrm{~mL}$ Erlenmeyer flask, under magnetic stirring at $400 \mathrm{rpm}$ for 20, 60, $120 \mathrm{~min}$, at room temperature. The sorbent has been removed by filtration and dried over night at $80^{\circ} \mathrm{C}$, so as to be further subjected to leaching studies and XRD-Analysis. The filtrate's $\mathrm{pH}$ has been measured and the element concentration after sorption has been determined by AAS.

In order to simulate wastewater deriving from electroplating, metal-finishing, paint and plastic manufacturing activities, batch experiments have also been carried out in a competitive solution containing $5 \mathrm{mg} / \mathrm{L} \mathrm{Cd}, 5 \mathrm{mg} / \mathrm{L} \mathrm{Pb}$, $100 \mathrm{mg} / \mathrm{L} \mathrm{Cu}$ and $100 \mathrm{mg} / \mathrm{L} \mathrm{Zn}$. Sorption has been studied under the aforementioned conditions, whereas as contact time 60min has been selected, since at this time an acceptable adsorption has been achieved.

The adsorption capacity (Eq. 1) of the sorbents in batch experiments has been determined according to the following relation:

$$
q=\frac{C_{i}-C_{f}}{m} \cdot V q
$$

(mg element per g sorbent) the adsorption capacity of the sorbent, $C_{i}(\mathrm{mg} / \mathrm{L})$ the initial concentration of each element in the solution and $C_{f}(\mathrm{mg} / \mathrm{L})$ the final concentration of each element in the solution after sorption, $m(\mathrm{~g})$ the mass of the sorbent used and $V(\mathrm{~L})$ the volume of the solution.

The \% adsorption (Eq. 2) for each element has been determined, in both batch and fixed bed conditions, according to the following relation:

$$
\operatorname{adsorption}(\%)=100 \cdot \frac{C_{i}-C_{f}}{C_{i}}
$$

Furthermore, in order to describe potentially toxic element adsorption on the different grain fractions of the examined materials, adsorption capacity has been studied as a function of concentration. Langmuir and Freundlich parameters have been calculated from the respective curves fitted to the experimental data, so as to find out how adsorption proceeds at higher solution concentrations (up to $500 \mathrm{mg} / \mathrm{L}$ ), since the aforementioned isotherm models have already been applied for the studied materials at lower concentrations $(<<5 \mathrm{mg} / \mathrm{L})[3,8,14]$.

Langmuir isotherm applies to adsorption on completely homogenous surfaces with negligible interaction between adsorbed molecules. Langmuir isotherm is given by the following relation (Eq. 3):

$$
q_{e}=q_{m} \frac{b C_{e}}{1+b C_{e}}
$$

where $q_{m}(\mathrm{mg} / \mathrm{g})$ is the maximum adsorption capacity related to the monolayer adsorption capacity, $b$ the Langmuir model constant. However, for the determination of favorability of sorption process the dimensionless constant 
separation factor $\left(R_{L}\right)$ is important, being defined by the following relation (Eq. 4):

$$
R_{L}=\frac{1}{1+b C_{o}}
$$

where $C_{o}(\mathrm{mg} / \mathrm{L})$ is the initial concentration of the elements. The $R_{L}$ indicates the type of isotherm, being either unfavorable $\left(R_{L}>1\right)$, linear $\left(R_{L}=1\right)$, favorable $\left(0<R_{L}<1\right)$ or irreversible $\left(R_{L}=0\right)$.

Freundlich isotherm is applied for non-ideal and reversible sorption, which is not limited to the formation of a monomolecular layer, and is determined by the following relation (Eq. 5):

$$
q_{e}=K_{F} C^{\frac{1}{n}}
$$

where $(\mathrm{mg} / \mathrm{g})$ and $n$ are the Freundlich parameters. A value $n>1$ indicates that element adsorption is favorable, whereas $n<1$ indicates unfavorable adsorption and $n=1$ linear adsorption.

For the estimation of particle size effect in comparison with other parameters, including solution concentration and contact time, Taguchi method has been applied. Taguchi method combines standard experimental design and analysis techniques, resulting in consistency and reproducibility which are rarely found in other statistical methods. It reduces the number of the required experimental tests, determines the optimal values for various factors and estimates the effect of each factor. As factors for the present study, three (3) parameters that is particle size, solution concentration and contact time have been selected, each one with 3 levels. In this case the L9 $\left(3^{3}\right)$ Taguchi design is proposed.

In Table 2 the set of the experimental tests proposed by the Taguchi method are shown. For the particle size, 3 levels have only been included $(-4 \mathrm{~mm}+1 \mathrm{~mm},-1 \mathrm{~mm}+$ $315 \mu \mathrm{m},-315 \mu \mathrm{m}+90 \mu \mathrm{m})$. The finest particle size $<90 \mu \mathrm{m}$

Table 2: Set of experimental tests according to L9 Taguchi design.

\begin{tabular}{ccc}
\hline particle size & $\begin{array}{c}\text { concentration } \\
(\mathrm{mg} / \mathrm{L})\end{array}$ & $\begin{array}{c}\text { contact time } \\
(\mathrm{min})\end{array}$ \\
\hline$-4 \mathrm{~mm}+1 \mathrm{~mm}$ & 5 & 20 \\
& 100 & 60 \\
& 500 & 120 \\
\hline$-1 \mathrm{~mm}+315 \mu \mathrm{m}$ & 5 & 60 \\
& 100 & 120 \\
& 500 & 20 \\
\hline$-315 \mu \mathrm{m}+90 \mu \mathrm{m}$ & 5 & 120 \\
& 100 & 20 \\
& 500 & 60 \\
\hline
\end{tabular}

has not been included, taking into account that the adsorption on this fraction is known to be high and the goal of the present study is to estimate whether the performance of the coarser fractions is satisfactory, in order to avoid grinding and/or sieving.

For the fixed bed experiments, samples of particle size $<1 \mathrm{~mm}$ (including fractions $-1 \mathrm{~mm}+315 \mu \mathrm{m},-315 \mu \mathrm{m}$ $+90 \mu \mathrm{m}$ and $<90 \mu \mathrm{m}$ ) have been used, as the adsorption results appeared to be more satisfying. The experiments have been based on the principles of the EN 14405 [20], determining the release of constituents from waste packed in a column with a leachant percolating through it, by using a continuous vertical up-flow. However, the conditions of the standard have been changed according to the needs of adsorption, since the standard refers to leaching and not adsorption. In particular, a plastic column of $30 \mathrm{~cm}$ height and $5 \mathrm{~cm}$ diameter has been used and a down flow at rate $1.25 \mathrm{~mL} / \mathrm{min}$ has been set by using a peristaltic pump so as to simulate the down flow of water in the soil. Twelve (12) consecutive filtrates of $100 \mathrm{~mL}$ have been collected. Their $\mathrm{pH}$ has been measured and the concentration of elements has been determined by AAS and ICP-AES. After collecting all the filtrates, a representative sample of the sorbent has been collected and dried at $80^{\circ} \mathrm{C}$ overnight, so as to be further subjected to XRD Analysis.

\section{Leaching studies}

After sorption studies, the collected sorbents have been subjected to leaching studies, so as to investigate the strength of adsorption of elements on the sorbents, taking into consideration the principles of EN12457-2 [21], that is a batch compliance test providing information on leaching at a liquid to solid ratio $10 \mathrm{~L} / \mathrm{kg}$ of granular wastes and sludges with a particle size below $4 \mathrm{~mm}$. In particular, deionised water has been applied as leachant under stirring for $24 \mathrm{~h}$ at $10 \mathrm{rpm}$. The $\mathrm{pH}$ and element concentration of the eluate have been determined and \% leaching of each element retained on the sorbent is given by the following relation (Eq. 6):

$$
\text { leaching }(\%)=100 \cdot \frac{C_{e l} \cdot V_{e l}}{m \cdot q}
$$

where $C_{e l}(\mathrm{mg} / \mathrm{L})$ the concentration of each element in the eluate, $V_{e l}(\mathrm{~L})$ the volume of the eluate, $m(\mathrm{~g})$ the mass of the sorbent used for the leaching studies and $q$ (mg element per $g$ sorbent) the adsorption capacity of the sorbent. 
Table 3: Physicochemical characteristics of the samples.

\begin{tabular}{ccccc}
\hline parameter & limestone & limestone marble & dolomite & dolomitic marble \\
\hline $\mathrm{CaO}(\%)$ & 55.4 & 55.0 & 31.9 & 33.1 \\
$\mathrm{MgO}(\%)$ & 0.30 & 0.72 & 20.3 & 19.3 \\
$\mathrm{SiO}_{2}(\%)$ & 0.23 & 0.49 & 0.27 & 0.52 \\
$\mathrm{Al}_{2} \mathrm{O}_{3}(\%)$ & 0.22 & 0.36 & 0.26 & 0.24 \\
$\mathrm{Fe}_{2} \mathrm{O}_{3}(\%)$ & 0.12 & 0.12 & 0.18 & 0.13 \\
$\mathrm{~K}_{2} \mathrm{O}(\%)$ & 0.14 & 0.01 & $<0.01$ \\
$\mathrm{Na}_{2} \mathrm{O}(\%)$ & 0.03 & $<0.01$ & $<0.01$ & $<0.01$ \\
$\mathrm{SO}(\%)$ & 0.01 & 0.02 & $<0.01$ \\
$\mathrm{Cu}(\mathrm{mg} / \mathrm{kg})$ & 0.05 & 76 & 10 & 89 \\
$\mathrm{Mn}(\mathrm{mg} / \mathrm{kg})$ & $<0.01$ & 180 & $<0.001$ & $<0.001$ \\
$\mathrm{Ni}(\mathrm{mg} / \mathrm{kg})$ & 70 & $<0.001$ & $<0.001$ & $<0.001$ \\
$\mathrm{P}(\mathrm{mg} / \mathrm{kg})$ & 17 & 270 & 50 & 33 \\
$\mathrm{Sr}(\mathrm{mg} / \mathrm{kg})$ & 340 & 420 & 170 & 310 \\
$\mathrm{Ti}(\mathrm{mg} / \mathrm{kg})$ & 700 & 220 & $<0.001$ & $<0.001$ \\
$\mathrm{Zn}(\mathrm{mg} / \mathrm{kg})$ & 44 & $<0.001$ & $<0.001$ & $<0.001$ \\
$\mathrm{LOI}(\%)$ & 94 & 43.2 & 47.5 & 46.7 \\
$\mathrm{pH}$ & 43.6 & 8.8 & 10.3 & 9.2 \\
$\mathrm{CEC}(\mathrm{meq} / 100 \mathrm{~g})$ & 9.0 & 4.7 & 4.3 & 4.9 \\
\hline
\end{tabular}

Table 4: CEC of sample fractions with different particle size.

\begin{tabular}{ccccc}
\hline particle size & \multicolumn{4}{c}{ CEC (meq/100g) } \\
\cline { 2 - 5 } & limestone & limestone marble & dolomite & dolomitic marble \\
\hline$-4 \mathrm{~mm}+1 \mathrm{~mm}$ & 4.45 & 3.70 & 4.65 & 3.66 \\
$-1 \mathrm{~mm}+315 \mu \mathrm{m}$ & 5.50 & 3.20 & 3.47 & 4.74 \\
$-315 \mu \mathrm{m}+90 \mu \mathrm{m}$ & 5.05 & 3.34 & 4.47 & 4.73 \\
$-90 \mu \mathrm{m}$ & 4.90 & 4.75 & 4.28 & 4.92 \\
total & 5.07 & 4.72 & 4.26 & 4.93 \\
\hline
\end{tabular}

\section{Results}

At first, the physicochemical characteristics of the samples are presented in Table 3, whereas CEC and porosity are analytically presented for each fraction of the materials in Tables 4 and 5 respectively.

Concerning the mineralogical characteristics of the samples, XRD analysis has confirmed the presence of calcite. Further analysis in a petrographic microscope has led to detection of apatite, muscovite and magnetite, whereas manganese oxides have been first detected by SEM analysis and then certified in the petrographic microscope.In all the dolomitic samples dolomite has also been detected. After adsorption on the materials formation of new crystalline phases has not been detected. This could be attributed to their low concentration.
In order to investigate the adsorption mechanisms, Langmuir and Freundlich isotherm models have been applied for all the material fractions. In Tables 6a-6d their parameters and correlation coefficients $\mathrm{R}^{2}$ are presented. As it is obvious, in almost all cases that is adsorption of all the examined elements $(\mathrm{Cd}, \mathrm{Cu}, \mathrm{Pb}, \mathrm{Zn})$ on all the fractions of all the materials, Langmuir isotherm model cannot be applied, since correlation coefficients are very low, which is also confirmed by negative $Q_{\max }$ and $b$ values that cannot correspond to a physical meaning. On the other hand, correlation coefficients $\sim 1$ indicate better application of Freundlich isotherm model. However, the value $n$ tends to be 1 , indicating rather a linear adsorption on the materials, except $\mathrm{Cd}$ adsorption on the coarsest fraction $(-4 \mathrm{~mm}+$ $1 \mathrm{~mm}$ ) of limestone marble which is favorable according to Langmuir isotherm model, since the correlation coefficient tends to 1 and is greater than the one of Freundlich model and $0<R_{L}<1$. The linear adsorption, observed almost in 
Table 5: Porosity of sample fractions with different particle size.

\begin{tabular}{cccc}
\hline particle size & $\begin{array}{c}\text { specific surface area } \\
\mathrm{S}_{B E T}\left(\mathrm{~m}^{2} / \mathrm{g}\right)\end{array}$ & $\begin{array}{c}\text { pore volume } \\
\mathrm{V}_{p}\left(\mathrm{~cm}^{3} / \mathrm{g}\right)\end{array}$ & $\begin{array}{c}\text { mean pore diameter } \\
\mathrm{d}_{p}(\AA)\end{array}$ \\
\hline$-1 \mathrm{~mm}+315 \mu \mathrm{m}$ & limestone & \\
$-90 \mu \mathrm{m}$ & 0.164 & 0.002 & 218.2 \\
\multicolumn{4}{c}{ limestone marble } \\
\hline$-1 \mathrm{~mm}+315 \mu \mathrm{m}$ & 0.149 & 0.003 & 160.2 \\
$-90 \mu \mathrm{m}$ & 0.862 & 0.001 & 98.3 \\
\hline \multicolumn{4}{c}{ dolomite } \\
\hline$-1 \mathrm{~mm}+315 \mu \mathrm{m}$ & 0.139 & 0.001 & 30.8 \\
$-90 \mu \mathrm{m}$ & 1.182 & 0.003 \\
\hline$-1 \mathrm{~mm}+315 \mu \mathrm{m}$ & 0.127 & 42.9 \\
\hline$-90 \mu \mathrm{m}$ & 0.740 & 0.002 & 41.0 \\
\hline
\end{tabular}

Table 6a: Langmuir and Freundlich isotherm parameters for $\mathrm{Cd}$ adsorption on limestone, dolomite and marble.

\begin{tabular}{|c|c|c|c|c|c|c|c|}
\hline \multirow[t]{2}{*}{ particle size } & \multicolumn{4}{|c|}{ Langmuir } & \multicolumn{3}{|c|}{ Freundlich } \\
\hline & $\mathrm{q}_{\max }(\mathrm{mg} / \mathrm{g})$ & $\mathrm{b}(\mathrm{L} / \mathrm{mg})$ & $\mathrm{R}_{L}$ & $\mathrm{R}^{2}$ & $\mathrm{n}$ & $\mathrm{K}_{F}(\mathrm{mg} / \mathrm{g})$ & $R^{2}$ \\
\hline \multicolumn{8}{|c|}{ limestone } \\
\hline$-4 m m+1 m m$ & $9.542 \cdot 10^{-1}$ & $6.292 \cdot 10^{-3}$ & 0.241 & 0.905 & 0.969 & 0.004 & 1.000 \\
\hline$-1 m m+315 \mu m$ & -8.190 & $-5.540 \cdot 10^{-4}$ & 1.383 & 0.415 & 1.009 & 0.004 & 1.000 \\
\hline$-315 \mu \mathrm{m}+90 \mu \mathrm{m}$ & -8.496 & $-5.387 \cdot 10^{-4}$ & 1.369 & 0.416 & 0.988 & 0.004 & 1.000 \\
\hline$-90 \mu \mathrm{m}$ & -8.347 & $-5.463 \cdot 10^{-4}$ & 1.376 & 0.415 & 0.948 & 0.003 & 0.995 \\
\hline \multicolumn{8}{|c|}{ limestone marble } \\
\hline$-4 m m+1 m m$ & $3.762 \cdot 10^{-1}$ & $2.949 \cdot 10^{-2}$ & 0.064 & 0.942 & 1.452 & 0.009 & 0.767 \\
\hline$-1 m m+315 \mu m$ & 1.595 & $3.182 \cdot 10^{-3}$ & 0.386 & 0.892 & 1.149 & 0.006 & 0.961 \\
\hline$-315 \mu \mathrm{m}+90 \mu \mathrm{m}$ & -8.696 & $-5.252 \cdot 10^{-4}$ & 1.356 & 0.407 & 0.916 & 0.004 & 0.999 \\
\hline$-90 \mu \mathrm{m}$ & -9.074 & $-5.048 \cdot 10^{-4}$ & 1.338 & 0.377 & 0.918 & 0.004 & 0.999 \\
\hline \multicolumn{8}{|c|}{ dolomite } \\
\hline$-4 m m+1 m m$ & $-1.035 \cdot 10^{-1}$ & $-4.412 \cdot 10^{-4}$ & 1.283 & 0.300 & 0.923 & 0.004 & 0.998 \\
\hline$-1 m m+315 \mu m$ & -8.217 & $-5.534 \cdot 10^{-4}$ & 1.383 & 0.419 & 0.912 & 0.004 & 0.999 \\
\hline$-315 \mu \mathrm{m}+90 \mu \mathrm{m}$ & 6.072 & $7.986 \cdot 10^{-4}$ & 0.715 & 0.418 & 1.016 & 0.005 & 0.984 \\
\hline$-90 \mu \mathrm{m}$ & $2.801 \cdot 10^{-1}$ & $1.680 \cdot 10^{-4}$ & 0.923 & 0.041 & 0.974 & 0.004 & 0.992 \\
\hline
\end{tabular}

all cases, is not in contrast with references [3, 8, 14], where either Langmuir or Freundlich model is applied at much lower concentrations ( $<<5 \mathrm{mg} / \mathrm{L})$, but adsorption tends to become linear as concentration increases.

In Figure 1a-1c potentially toxic element adsorption on limestone, dolomite and marble from monoelement solutions of different concentration is illustrated as a function of time. Results for dolomitic marble are not presented in this Figure, because they have been carried out only for the fraction $-1 \mathrm{~mm}+315 \mu \mathrm{m}$, since as it results from Figure 1a$1 \mathrm{c}$ it performs better than the coarsest one $-4 \mathrm{~mm}+1 \mathrm{~mm}$ in most cases, after adsorption reaches equilibrium $(2 \mathrm{~h})$.
The finest ones have not been selected, since their better performance is expected, whereas the goal of the present study is to investigate whether the coarsest ones perform as well as the finest ones, in order to avoid grinding of the materials.

As it is obvious from the Figures 1a-1c, adsorption from solutions with very low concentration $(5 \mathrm{mg} / \mathrm{L})$ stabilizes after $1 \mathrm{~h}$. Adsorption on limestone at $100 \mathrm{mg} / \mathrm{L}$ stabilizes for all elements after $1 \mathrm{~h}$, except in case of $\mathrm{Zn}$ whose adsorption increases slightly after $1 \mathrm{~h}$. Adsorption on limestone marble at $100 \mathrm{mg} / \mathrm{L}$ is similar with that on limestone, whereas an important increase in $\mathrm{Cd}$ and Cu adsorp- 
Table 6b: Langmuir and Freundlich isotherm parameters for $\mathrm{Cu}$ adsorption on limestone, dolomite and marble.

\begin{tabular}{|c|c|c|c|c|c|c|c|}
\hline \multirow[t]{2}{*}{ particle size } & \multicolumn{4}{|c|}{ Langmuir } & \multicolumn{3}{|c|}{ Freundlich } \\
\hline & $\mathrm{q}_{\max }(\mathrm{mg} / \mathrm{g})$ & $\mathrm{b}(\mathrm{L} / \mathrm{mg})$ & $\mathrm{R}_{L}$ & $\mathrm{R}^{2}$ & $\mathrm{n}$ & $\mathrm{K}_{F}(\mathrm{mg} / \mathrm{g})$ & $\mathrm{R}^{2}$ \\
\hline \multicolumn{8}{|c|}{ limestone } \\
\hline$-4 m m+1 m m$ & -8.333 & $-5.463 \cdot 10^{-4}$ & 1.376 & 0.419 & 0.914 & 0.004 & 0.999 \\
\hline$-1 m m+315 \mu m$ & -8.163 & $-5.548 \cdot 10^{-4}$ & 1.384 & 0.437 & 0.913 & 0.004 & 0.999 \\
\hline$-315 \mu \mathrm{m}+90 \mu \mathrm{m}$ & -8.340 & $-5.466 \cdot 10^{-4}$ & 1.376 & 0.428 & 0.914 & 0.004 & 0.999 \\
\hline$-90 \mu \mathrm{m}$ & -8.525 & $-5.349 \cdot 10^{-4}$ & 1.365 & 0.408 & 0.915 & 0.004 & 0.999 \\
\hline \multicolumn{8}{|c|}{ limestone marble } \\
\hline$-4 m m+1 m m$ & $1.176 \cdot 10^{-2}$ & $3.884 \cdot 10^{-5}$ & 0.981 & 0.002 & 0.960 & 0.004 & 0.993 \\
\hline$-1 m m+315 \mu m$ & -7.564 & $-5.832 \cdot 10^{-4}$ & 1.412 & 0.524 & 0.910 & 0.003 & 1.000 \\
\hline$-315 \mu \mathrm{m}+90 \mu \mathrm{m}$ & -8.224 & $-5.528 \cdot 10^{-4}$ & 1.382 & 0.424 & 0.910 & 0.004 & 0.999 \\
\hline$-90 \mu \mathrm{m}$ & -8.143 & $3.854 \cdot 10^{-5}$ & 0.981 & 0.421 & 0.910 & 0.003 & 0.999 \\
\hline \multicolumn{8}{|c|}{ dolomite } \\
\hline$-4 m m+1 m m$ & -6.553 & $-6.534 \cdot 10^{-4}$ & 1.485 & 0.417 & 0.897 & 0.003 & 0.999 \\
\hline$-1 m m+315 \mu m$ & -8.299 & $-5.498 \cdot 10^{-4}$ & 1.379 & 0.422 & 0.913 & 0.004 & 0.999 \\
\hline$-315 \mu \mathrm{m}+90 \mu \mathrm{m}$ & -7.468 & $-5.251 \cdot 10^{-4}$ & 1.356 & 0.422 & 0.906 & 0.003 & 0.999 \\
\hline$-90 \mu \mathrm{m}$ & -7.698 & $-5.817 \cdot 10^{-4}$ & 1.410 & 0.424 & 0.908 & 0.003 & 0.999 \\
\hline
\end{tabular}

Table 6c: Langmuir and Freundlich isotherm parameters for $\mathrm{Pb}$ adsorption on limestone, dolomite and marble.

\begin{tabular}{cccccccc}
\hline \multirow{2}{*}{ particle size } & \multicolumn{9}{c}{ Langmuir } & \multicolumn{3}{c}{ Freundlich } \\
\cline { 2 - 8 } & $\mathrm{q}_{\max }(\mathrm{mg} / \mathrm{g})$ & $\mathrm{b}(\mathrm{L} / \mathrm{mg})$ & $\mathrm{R}_{L}$ & $\mathrm{R}^{2}$ & $\mathrm{n}$ & $\mathrm{K}_{F}(\mathrm{mg} / \mathrm{g})$ & $\mathrm{R}^{2}$ \\
\hline \multicolumn{7}{c}{ limestone } \\
\hline$-4 \mathrm{~mm}+1 \mathrm{~mm}$ & $-1.252 \cdot 10^{-1}$ & $-3.952 \cdot 10^{-4}$ & 1.246 & 0.429 & 0.938 & 0.004 & 1.000 \\
$-1 \mathrm{~mm}+315 \mu \mathrm{m}$ & -9.328 & $-5.013 \cdot 10^{-4}$ & 1.334 & 0.427 & 0.921 & 0.004 & 0.999 \\
$-315 \mu \mathrm{m}+90 \mu \mathrm{m}$ & -7.740 & $-5.782 \cdot 10^{-4}$ & 1.407 & 0.424 & 0.909 & 0.003 & 0.999 \\
$-90 \mu \mathrm{m}$ & -6.570 & $-6.521 \cdot 10^{-4}$ & 1.484 & 0.423 & 0.897 & 0.003 & 0.999 \\
\hline \multicolumn{7}{c}{ limestone marble } \\
\hline$-4 \mathrm{~mm}+1 \mathrm{~mm}$ & $-1.706 \cdot 10^{-1}$ & $-3.025 \cdot 10^{-4}$ & 1.178 & 0.428 & 0.952 & 0.004 & 1.000 \\
$-1 \mathrm{~mm}+315 \mu \mathrm{m}$ & $-1.335 \cdot 10^{-1}$ & $-3.747 \cdot 10^{-4}$ & 1.231 & 0.419 & 0.940 & 0.004 & 1.000 \\
$-315 \mu \mathrm{m}+90 \mu \mathrm{m}$ & -5.970 & $-6.962 \cdot 10^{-4}$ & 1.534 & 0.422 & 0.890 & 0.003 & 0.998 \\
$-90 \mu \mathrm{m}$ & $-1.328 \cdot 10^{-1}$ & $-3.762 \cdot 10^{-4}$ & 1.232 & 0.418 & 0.940 & 0.004 & 1.000 \\
\hline \multicolumn{7}{c}{ dolomite } \\
\hline$-4 \mathrm{~mm}+1 \mathrm{~mm}$ & -6.053 & $-6.905 \cdot 10^{-4}$ & 1.527 & 0.424 & 0.891 & 0.003 & 0.999 \\
$-41 \mathrm{~mm}+315 \mu \mathrm{m}$ & -8.389 & $-5.446 \cdot 10^{-4}$ & 1.374 & 0.430 & 0.914 & 0.004 & 0.999 \\
$-315 \mu \mathrm{m}+90 \mu \mathrm{m}$ & -6.456 & $-6.607 \cdot 10^{-4}$ & 1.493 & 0.425 & 0.896 & 0.003 & 0.999 \\
$-90 \mu \mathrm{m}$ & -6.105 & $-6.866 \cdot 10^{-4}$ & 1.523 & 0.417 & 0.892 & 0.003 & 0.998 \\
\hline
\end{tabular}

tion on the coarsest fraction is observed at $2 \mathrm{~h}$. Adsorption on dolomite at $100 \mathrm{mg} / \mathrm{L}$ also stabilizes after $1 \mathrm{~h}$, except in case of $\mathrm{Zn}$ whose adsorption on the finer fractions decreases slightly or more intensely after $2 \mathrm{~h}$. At $500 \mathrm{mg} / \mathrm{L}$ $\mathrm{Cd}$ and $\mathrm{Pb}$ adsorption on limestone and its marble stabilizes after $\mathrm{lh}$, whereas $\mathrm{Cu}$ and $\mathrm{Zn}$ adsorption increases. In case of limestone marble a slight decrease in $\mathrm{Cd}$ and $\mathrm{Cu}$ adsorption on the coarsest fractions is observed. Adsorption on dolomite increases almost in all cases after $1 \mathrm{~h}$, except
$\mathrm{Pb}$ adsorption which stabilizes, and $\mathrm{Cd}$ adsorption on the fine fraction $-315 \mu \mathrm{m}+90 \mu \mathrm{m}$, which decreases after $1 \mathrm{~h}$.

Concerning the particle size effect, at $5 \mathrm{mg} / \mathrm{L}$ no significant difference in adsorption on all material fractions with different particle size is observed after $1 \mathrm{~h}$, except a difference between all material fractions by up to $15 \%$ observed in $\mathrm{Pb}$ adsorption. At $100 \mathrm{mg} / \mathrm{L}$ respectively significant differences in adsorption on material fractions with different particle size are observed only in case of $\mathrm{Zn}$ adsorption on 
Table 6d: Langmuir and Freundlich isotherm parameters for $\mathrm{Zn}$ adsorption on limestone, dolomite and marble.

\begin{tabular}{|c|c|c|c|c|c|c|c|}
\hline \multirow{2}{*}{ particle size } & \multicolumn{4}{|c|}{ Langmuir } & \multicolumn{3}{|c|}{ Freundlich } \\
\hline & $\mathrm{q}_{\max }(\mathrm{mg} / \mathrm{g})$ & $\mathrm{b}(\mathrm{L} / \mathrm{mg})$ & $\mathrm{R}_{L}$ & $\mathrm{R}^{2}$ & $\mathrm{n}$ & $\mathrm{K}_{F}(\mathrm{mg} / \mathrm{g})$ & $\mathrm{R}^{2}$ \\
\hline \multicolumn{8}{|c|}{ limestone } \\
\hline$-4 m m+1 m m$ & $-2.632 \cdot 10^{-1}$ & $-1.503 \cdot 10^{-4}$ & 1.081 & 0.182 & 0.969 & 0.004 & 1.000 \\
\hline$-1 \mathrm{~mm}+315 \mu \mathrm{m}$ & $4.587 \cdot 10^{-1}$ & $8.533 \cdot 10^{-5}$ & 0.959 & 0.986 & 0.988 & 0.004 & 1.000 \\
\hline$-315 \mu \mathrm{m}+90 \mu \mathrm{m}$ & $-2.841 \cdot 10^{-1}$ & $-1.375 \cdot 10^{-4}$ & 1.074 & 0.925 & 0.995 & 0.003 & 1.000 \\
\hline$-90 \mu \mathrm{m}$ & -5.208 & $-6.068 \cdot 10^{-4}$ & 1.436 & 0.812 & 0.998 & 0.092 & 0.995 \\
\hline \multicolumn{8}{|c|}{ limestone marble } \\
\hline$-4 m m+1 m m$ & -4.965 & $-5.923 \cdot 10^{-4}$ & 1.421 & 0.586 & 0.960 & 0.003 & 0.992 \\
\hline$-1 m m+315 \mu m$ & $-2.604 \cdot 10^{-1}$ & $-1.632 \cdot 10^{-4}$ & 1.089 & 0.185 & 0.966 & 0.004 & 0.999 \\
\hline$-315 \mu \mathrm{m}+90 \mu \mathrm{m}$ & $-2.004 \cdot 10^{-1}$ & $-2.068 \cdot 10^{-4}$ & 0.241 & 0.241 & 0.961 & 0.004 & 0.999 \\
\hline$-90 \mu \mathrm{m}$ & $1.650 \cdot 10^{-1}$ & $2.515 \cdot 10^{-4}$ & 0.888 & 0.405 & 1.007 & 0.004 & 0.998 \\
\hline \multicolumn{8}{|c|}{ dolomite } \\
\hline$-4 m m+1 m m$ & 3.619 & $1.353 \cdot 10^{-3}$ & 0.596 & 0.605 & 1.045 & 0.005 & 0.975 \\
\hline$-1 m m+315 \mu m$ & -5.345 & $-6.599 \cdot 10^{-4}$ & 1.492 & 0.701 & 0.948 & 0.003 & 0.992 \\
\hline$-315 \mu \mathrm{m}+90 \mu \mathrm{m}$ & 5.750 & $7.865 \cdot 10^{-4}$ & 0.718 & 0.477 & 1.021 & 0.004 & 0.987 \\
\hline$-90 \mu \mathrm{m}$ & -7.479 & $-5.643 \cdot 10^{-4}$ & 1.393 & 0.482 & 0.914 & 0.003 & 0.999 \\
\hline
\end{tabular}

Table 7: Effect of particle size, concentration and contact time on potentially toxic element adsorption on limestone, limestone marble and dolomite, as resulting from the Taguchi method.

\begin{tabular}{ccccc}
\hline element & \multicolumn{4}{c}{ \% effect } \\
\cline { 2 - 5 } & particle size & concentration & contact time & other \\
\hline \multicolumn{5}{c}{ limestone } \\
$\mathrm{Cd}$ & 19.18 & 43.57 & 17.67 & 19.58 \\
$\mathrm{Cu}$ & 23.71 & 22.54 & 28.55 & 25.2 \\
$\mathrm{~Pb}$ & 0.60 & 98.09 & 0.58 & 0.73 \\
$\mathrm{Zn}$ & 5.36 & 21.67 & 46.88 & 26.09 \\
\hline \multicolumn{5}{c}{ limestone marble } \\
$\mathrm{Cd}$ & 31.93 & 40.20 & 1.04 \\
$\mathrm{Cu}$ & 13.23 & 34.74 & 10.12 & 26.83 \\
$\mathrm{~Pb}$ & 2.08 & 94.11 & 1.85 \\
$\mathrm{Zn}$ & 2.86 & 45.18 & 45.04 & 1.96 \\
\hline $\mathrm{Cd}$ & dolomite & 6.92 \\
\hline $\mathrm{Cu}$ & 24.84 & 16.64 & 20.18 \\
$\mathrm{~Pb}$ & 16.09 & 12.54 & 54.94 & 38.34 \\
$\mathrm{Zn}$ & 1.35 & 98.05 & 0.23 & 16.43 \\
\hline
\end{tabular}

all the materials, which is in the order of $20-30 \%$. However, it is not the finest fractions that exhibit the best behaviour and the coarsest one the worst behaviour for all materials. At $500 \mathrm{mg} / \mathrm{L}$ significant differences are observed after $2 \mathrm{~h}$ for $\mathrm{Zn}$ adsorption on material fractions with different particle size, however not exceeding $15 \%$ in case of limestone and its marble and rising up to $50 \%$ in case of dolomite. Furthermore, differences in Cd adsorption at $500 \mathrm{mg} / \mathrm{L}$ are observed between the fractions, however not leading to an obvious result.

In general, after equilibrium is achieved $(2 \mathrm{~h})$, the fractions of coarser particle size exhibit in most cases a comparable performance to that of the finer ones. In order to certify this result, Taguchi method has been applied, estimating the effect of particle size in comparison with solution concentration, contact time and other parameters, including temperature, $\mathrm{pH}$, solution environment. In Table 7 


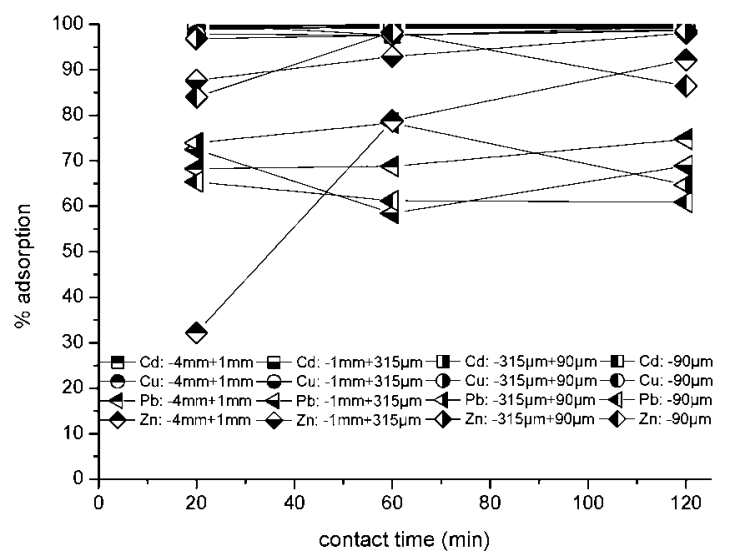

$5 \mathrm{mg} / \mathrm{L}$

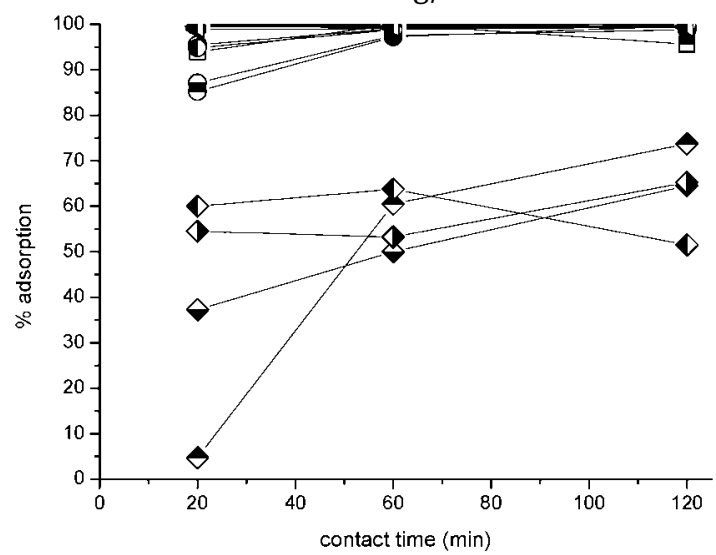

$100 \mathrm{mg} / \mathrm{L}$

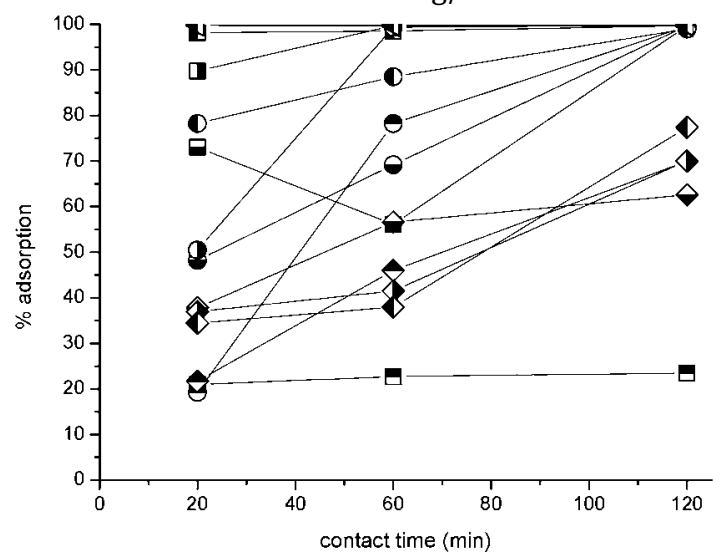

$500 \mathrm{mg} / \mathrm{L}$

Figure 1a: \% Adsorption of potentially toxic elements as a function of time on limestone fractions of different particle size from monoelement solutions at $5,100,500 \mathrm{mg} / \mathrm{L}$.

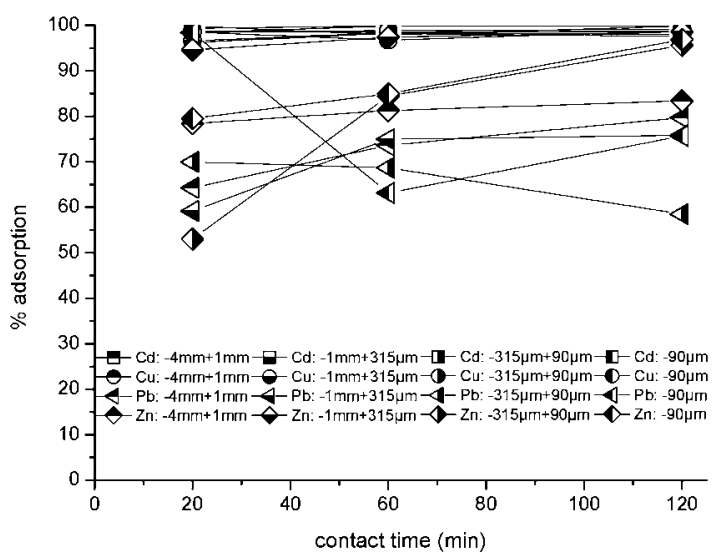

$5 \mathrm{mg} / \mathrm{L}$

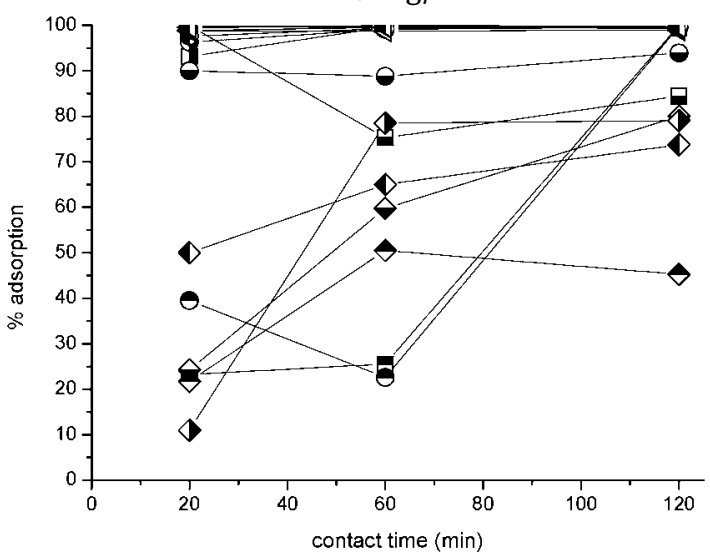

$100 \mathrm{mg} / \mathrm{L}$

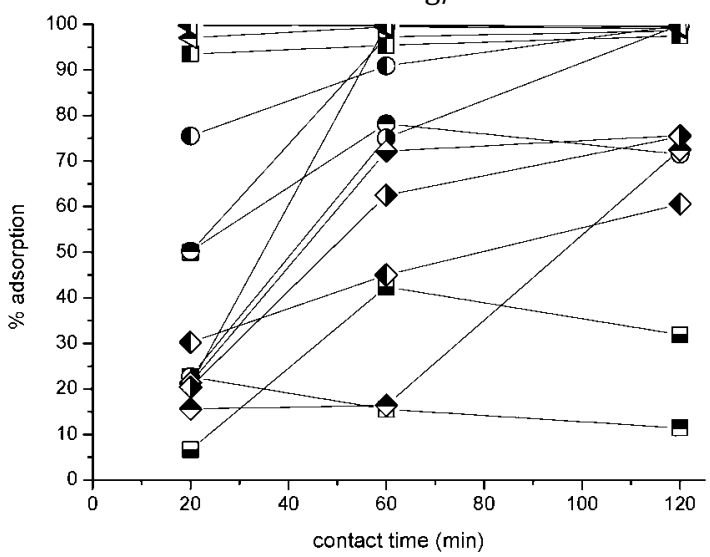

$500 \mathrm{mg} / \mathrm{L}$

Figure 1b: \% Adsorption of potentially toxic elements as a function of time on limestone marble fractions of different particle size from monoelement solutions at $5,100,500 \mathrm{mg} / \mathrm{L}$. 

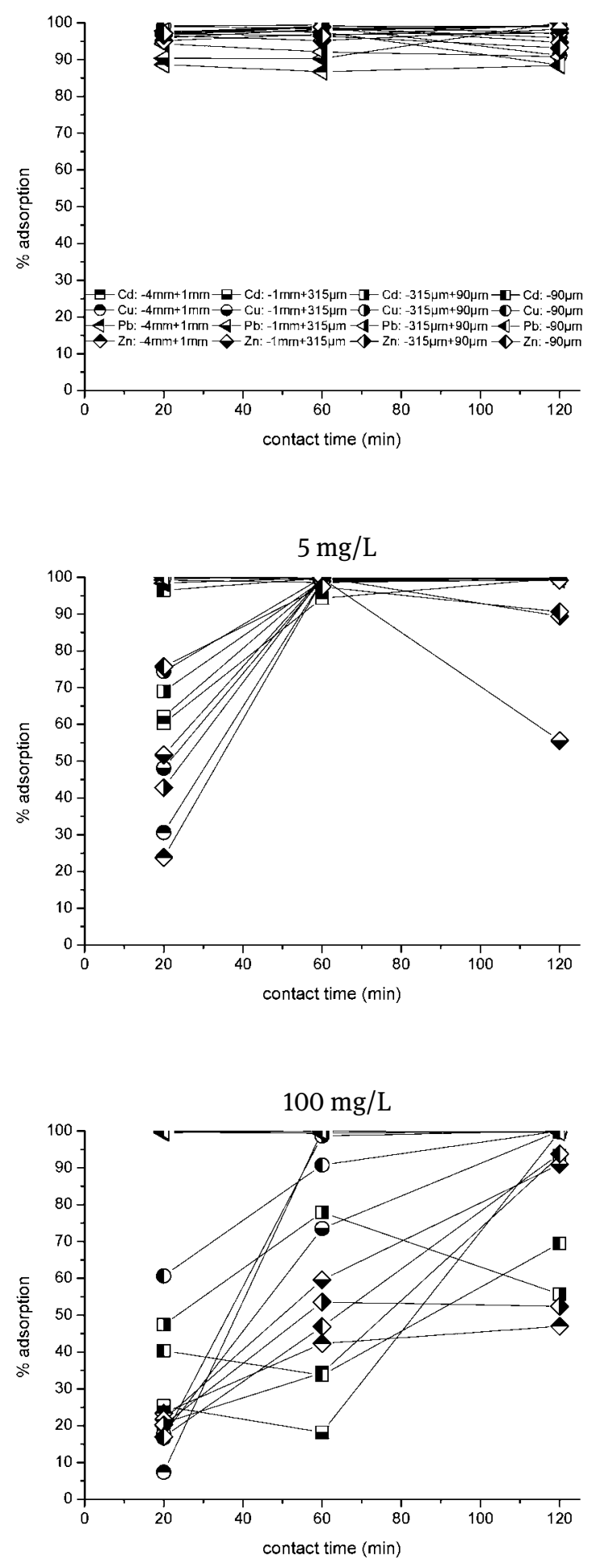

$500 \mathrm{mg} / \mathrm{L}$

Figure 1c: \% Adsorption of potentially toxic elements as a function of time on dolomite fractions of different particle size from monoelement solutions at $5,100,500 \mathrm{mg} / \mathrm{L}$. the effect of each parameter is shown, as resulting from the Taguchi method.

As it results from Table 7, the effect of particle size on $\mathrm{Zn}$ adsorption on all studied materials is much lower than the one of other parameters. $\mathrm{Pb}$ adsorption is obviously determined by solution concentration. Cd adsorption seems to be determined by concentration in case of limestone and its marble, whereas in case of dolomite the effect of particle size and contact time is similar and not the strongest one. $\mathrm{Cu}$ adsorption seems to be determined by concentration in case of limestone marble and by contact time in case of dolomite, whereas in case of limestone all parameters have a similar effect on adsorption. Therefore, in almost all cases particle size has been proven not to be the most determinative parameter in adsorption.

As it has already been explained, since the performance of the fractions $-1 \mathrm{~mm}+315 \mu \mathrm{m},-315 \mu \mathrm{m}+90 \mu \mathrm{m}$ and $<90 \mu \mathrm{m}$ is better than that of the coarsest one $-4 \mathrm{~mm}+$ $1 \mathrm{~mm}$ in most cases, for the experiments in fixed bed conditions, which simulate real conditions, the fraction $<1 \mathrm{~mm}$, including all the aforementioned finest fractions, has been selected.

As it can be observed in Figure 2, the adsorption of potentially toxic elements $(\mathrm{Cd}, \mathrm{Cu}, \mathrm{Pb}, \mathrm{Zn})$ from monoelement solutions differs a lot from their adsorption from a competitive solution. In particular, $\mathrm{Cd}$ and $\mathrm{Cu}$ adsorption from monoelement solutions on all the materials is significantly high, varying from 89 to almost $100 \%$. Pb and $\mathrm{Zn}$ adsorption on dolomite and its marble is higher, rising up to $90-100 \%$, whereas it varies from 50 to $75 \%$ on limestone and its marble. In contrast, $\mathrm{Cu}$ and $\mathrm{Pb}$ adsorption from a competitive solution on all the materials is high and in some cases even higher than their adsorption from monoelement solutions, whereas $\mathrm{Cd}$ and $\mathrm{Zn}$ adsorption from a competitive solution on all the materials, except limestone, is significantly lower than their adsorption from monoelement solutions, varying from 17 to $55 \%$. Furthermore, a significant difference is observed in $\mathrm{Cd}$ and $\mathrm{Zn}$ adsorption from a competitive solution on limestone and its marble. In particular, $\mathrm{Cd}$ and $\mathrm{Zn}$ adsorption is three times lower on limestone marble than on limestone.

In Table 8 the adsorption capacity $q$ (mg of element per $g$ of sorbent) of all the samples, that is limestone and its marble, dolomite and its marble, for all the studied elements $(\mathrm{Cd}, \mathrm{Cu}, \mathrm{Pb}, \mathrm{Zn}$ ) from both monoelement and competitive solutions is given.

In general, no significant differences in adsorption capacity are observed between each rock (limestone, dolomite) and its marble. Limestone and dolomite and their marbles have a similar adsorption capacity for $\mathrm{Cd}$ and $\mathrm{Cu}$, rising up to $0.030 \mathrm{mg} \mathrm{Cd}$ per $\mathrm{g}$ and $0.53-0.60 \mathrm{mg} \mathrm{Cu}$ per 
Table 8: Adsorption capacity of the fraction $-1 \mathrm{~mm}+315 \mu \mathrm{m}$ of the samples in monoelement and competitive solutions of potentially toxic elements.

\begin{tabular}{cccccc}
\hline sorbent material & solution & \multicolumn{4}{c}{ adsorption capacity $q(\mathrm{mg} / \mathrm{g}$ sorbent $)$} \\
\cline { 3 - 5 } & & $\mathrm{Cd}$ & $\mathrm{Cu}$ & $\mathrm{Pb}$ & $\mathrm{Zn}$ \\
\hline limestone & monoelement & 0.030 & 0.59 & 0.018 & 0.30 \\
& competitive & 0.030 & 0.60 & 0.025 & 0.52 \\
limestone marble & monoelement & 0.030 & 0.53 & 0.022 & 0.36 \\
& competitive & 0.007 & 0.59 & 0.026 & 0.10 \\
dolomite & monoelement & 0.030 & 0.60 & 0.029 & 0.60 \\
& competitive & 0.015 & 0.58 & 0.028 & 0.33 \\
dolomitic marble & monoelement & 0.030 & 0.60 & 0.029 & 0.59 \\
& competitive & 0.011 & 0.57 & 0.029 & 0.21 \\
\hline
\end{tabular}

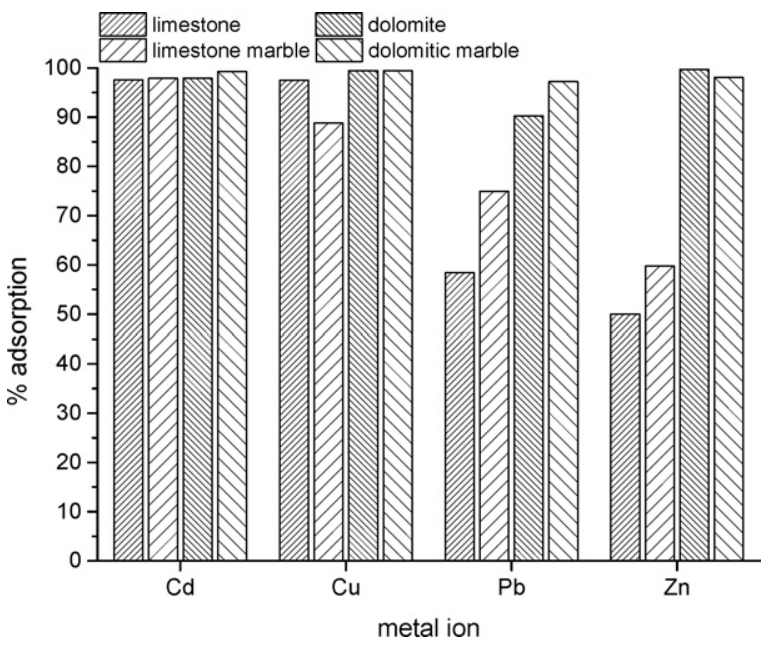

(a)

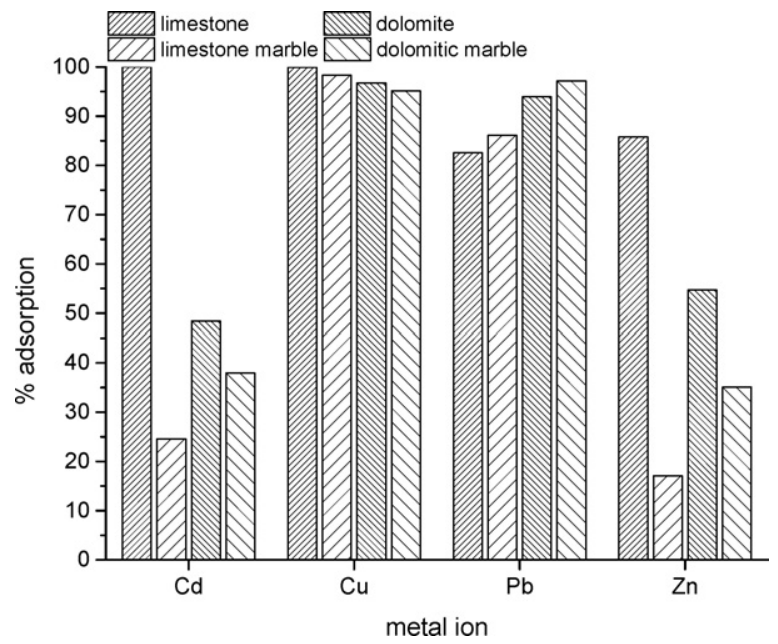

(b)

Figure 2: Adsorption \% of potentially toxic elements from (a) monoelement solutions and (b) a competitive solution on the fraction -1mm + $315 \mu \mathrm{m}$ of the materials.

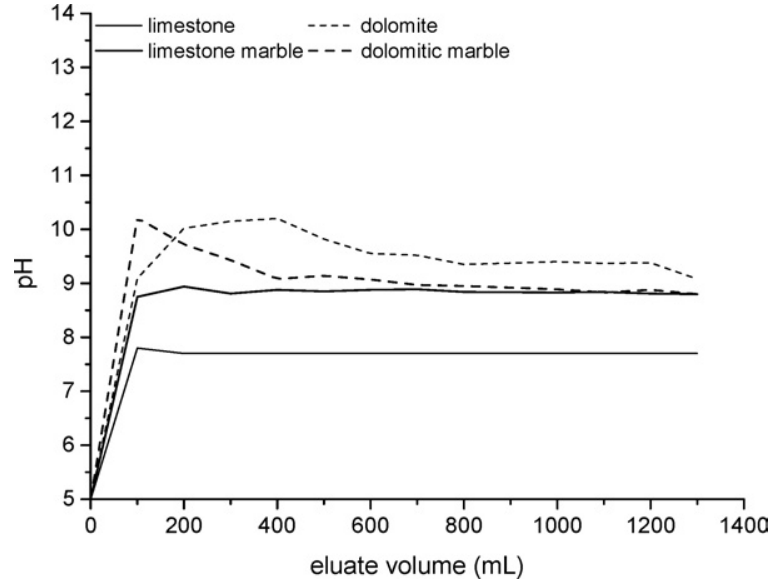

Figure 3: Eluate $\mathrm{pH}$ during potentially toxic element adsorption on the samples in fixed bed conditions. $\mathrm{g}$, whereas dolomite and its marble have a higher adsorption capacity for $\mathrm{Pb}$ and $\mathrm{Zn}$, rising up to $0.029 \mathrm{mg} \mathrm{Pb}$ per $\mathrm{g}$ and 0.59-0.60 $\mathrm{mg} \mathrm{Zn} \mathrm{per} \mathrm{g}$, than that of limestone and its marble, rising up to $0.018-0.022 \mathrm{mg} \mathrm{Pb}$ per $\mathrm{g}$ and 0.30-0.36 mg Zn per g.

Differences are observed also in the adsorption capacity achieved for each element in monoelement solutions and a competitive solution. In particular, a decrease by 45$75 \%$ in $\mathrm{Cd}$ and $\mathrm{Zn}$ adsorption capacity of all the materials is observed in a competitive solution, except limestone, whose $\mathrm{Cd}$ adsorption capacity remains the same and $\mathrm{Zn}$ adsorption capacity increases by $73 \%$. No significant differences in $\mathrm{Cu}$ adsorption capacity of all materials and also in $\mathrm{Pb}$ adsorption capacity of dolomite and its marble are observed, whereas in case of limestone and its marble, an increase in $\mathrm{Pb}$ adsorption capacity by $18-39 \%$ is observed. The differences in adsorption capacity between monoele- 


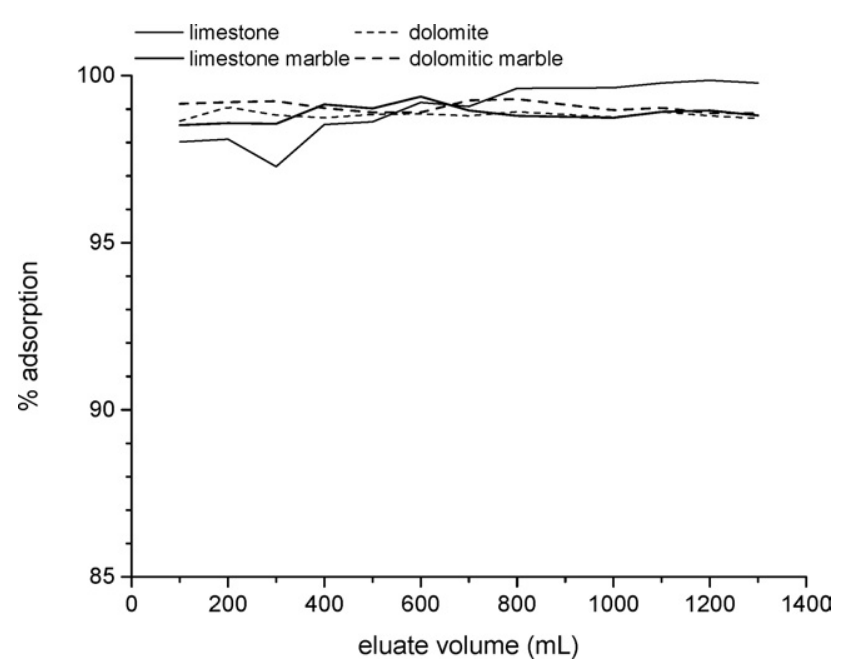

(a)

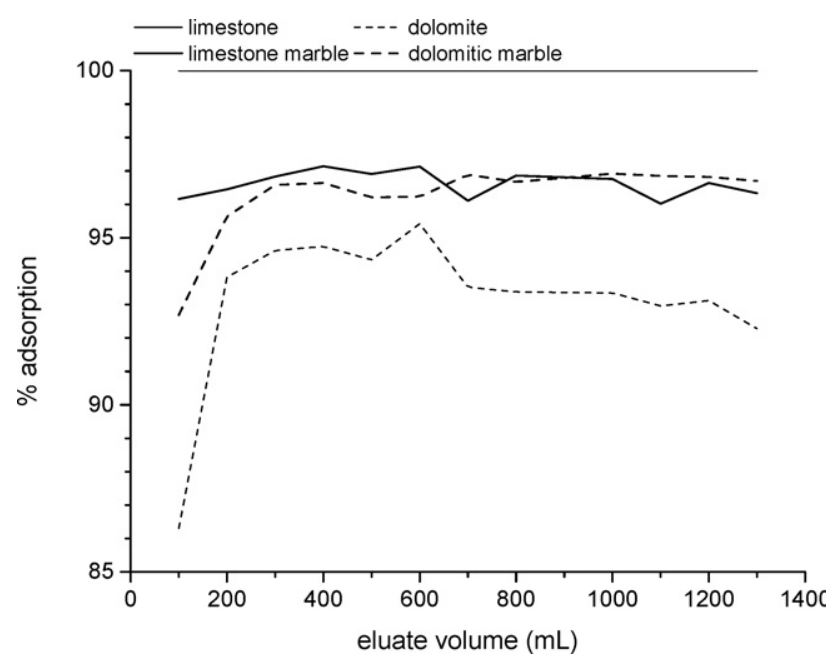

(c)

Figure 4: Adsorption \% of potentially toxic elements $\mathrm{Cd}(\mathrm{a}), \mathrm{Cu}(\mathrm{b}), \mathrm{Pb}(\mathrm{c}), \mathrm{Zn}(\mathrm{d})$ on the samples in fixed bed conditions.

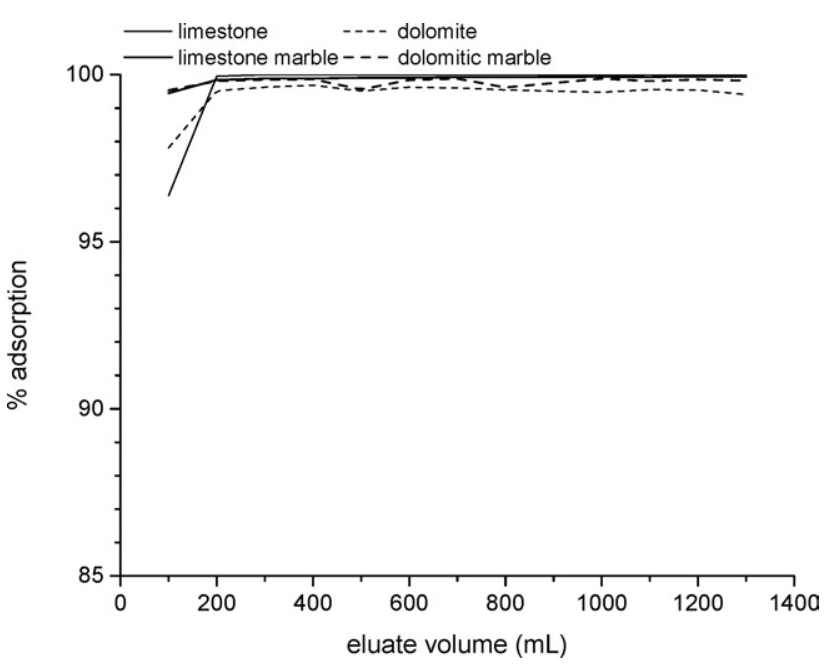

(b)

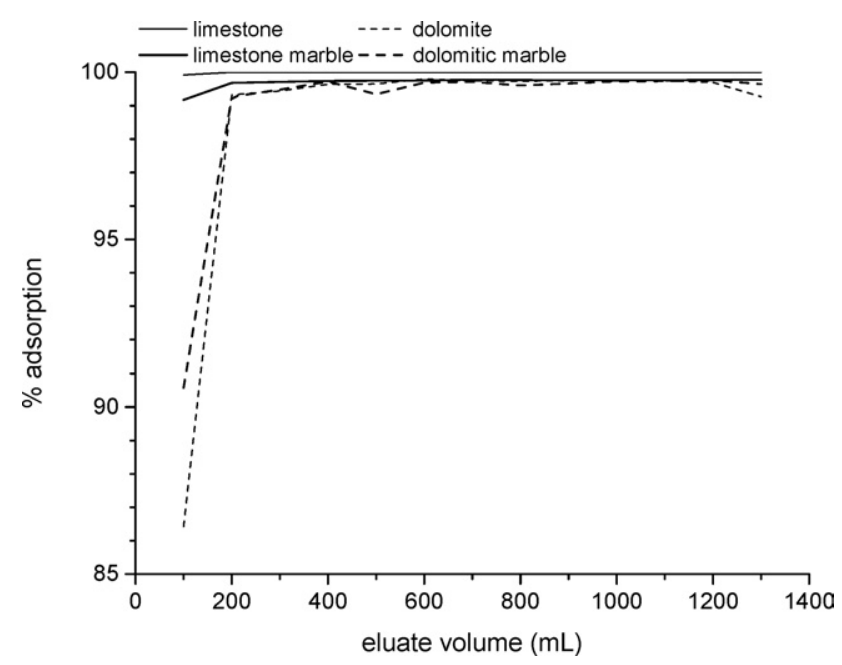

(d) ment and competitive solutions are in accordance with the ones observed in adsorption $\%$.

The leaching of the elements $(\mathrm{Cd}, \mathrm{Cu}, \mathrm{Pb}, \mathrm{Zn})$ being retained on all the materials, after adsorption in batch conditions, does not exceed $4 \%$, indicating that they are sufficiently retained on the rocks' surface.

In Figure 3 and 4 the $\mathrm{pH}$ of the eluate and the adsorption $\%$ of the potentially toxic elements $(\mathrm{Cd}, \mathrm{Cu}, \mathrm{Pb}, \mathrm{Zn})$ during adsorption on all the mineral tailings, that is limestone and its marble, dolomite and its marble, in fixed bed conditions, are respectively illustrated.

Concerning the $\mathrm{pH}$ of the eluate during adsorption in fixed bed conditions, an initial increase at the first eluate $(100 \mathrm{~mL})$ and then its stabilization is observed for all the materials. The $\mathrm{pH}$ is stabilized at a different point for each material. For limestone and its marble it is stabilized at 7.79, whereas for dolomite and its marble at 9-9.5.

As it is obvious from Figure 4, as the first $200 \mathrm{~mL}$ of solution have passed through the bed, the adsorption on all the materials is in most cases stabilized at its maximum, varying from 93 to almost 100\%. Furthermore, even the initial adsorption, estimated by the first eluate, coming up to $86-99 \%$, is considered high. Total adsorption of $\mathrm{Cu}$ and $\mathrm{Zn}$ is achieved on all the materials in fixed bed conditions. In case of $\mathrm{Cd}$ and $\mathrm{Pb}$ a variance in adsorption is observed until $800 \mathrm{~mL}$ of solution has passed through the bed, however, it cannot be considered significant, since it is in the order of $1-2 \%$. Dolomite and its marble and limestone marble exhibit a lower performance in $\mathrm{Pb}$ adsorption in fixed 
bed conditions, however satisfying, since it is greater than $93 \%$.

\section{Discussion}

According to the aforementioned presentation of the experimental results, when equilibrium is achieved after $2 \mathrm{~h}$, no significant differences in adsorption on fractions with different particle size can be observed, except in case of $\mathrm{Cd}$ and $\mathrm{Zn}$ at higher solution concentrations and $\mathrm{Pb}$ at low concentration. However, the differences observed do not indicate that in any case the coarsest fraction exhibits the worst performance. In contrast, coarser fractions exhibit in most cases a satisfactory performance, comparable to that of the finer ones.

This fact has also been certified by application of Taguchi method, indicating that the particle size could not be considered as the determinative parameter in potentially toxic element adsorption on the studied materials. This is also in accordance with the fact that there is no statistically significant difference in CEC among the fractions with different particle size of each material, as it has been determined using SPSS software. This result leads to the encouraging conclusion that a grinding and/or sieving process for achieving a fine particle size of the rocks is not considered necessary, relieving thus their further application from an extra financial burden.

As far as it concerns the adsorption capacity of the studied materials, limestone differentiates from dolomite in $\mathrm{Zn}$ adsorption, which could be attributed to the ionic radius of $\mathrm{Zn}^{2+}$, which is similar to the one of $\mathrm{Mg}^{2+}$ compared to the one of $\mathrm{Ca}^{2+}$, favouring thus its exchange with $\mathrm{Mg}^{2+}$ rather than with $\mathrm{Ca}^{2+}$, as it has already been mentioned [26, 27]. However, no significant differentiation between each rock and its marble has been observed.

Another view of potentially toxic element adsorption on carbonate minerals on which focuses the present study is adsorption from a competitive solution, in order to simulate real waste streams. Preferable $\mathrm{Cu}$ and $\mathrm{Pb}$ adsorption from a competitive solution in comparison to $\mathrm{Cd}$ and $\mathrm{Zn}$ adsorption on the studied materials could be attributed to the adsorption mechanisms for the studied elements. In particular, $\mathrm{Cu}^{2+}$ ions are adsorbed very strongly and fast (within 1min) on calcite surface, since $\mathrm{Cu}^{2+}$ ions are smaller than $\mathrm{Ca}^{2+}$ ions and are incorporated into the crystal lattice [22]. Furthermore, the formation of $\mathrm{Cu}$ carbonate and $\mathrm{Cu}$ hydroxide complexes contributes to retention of $\mathrm{Cu}^{2+}$ ions on calcite surface [23]. $\mathrm{Pb}^{2+}$ adsorption on calcite is also rapid within the first minute, but contin- ues slowly, indicating a primary reversible $\mathrm{Pb}^{2+}$ binding to the calcite surface, possibly via a co-precipitation mechanism, and some re-arrangement of $\mathrm{Pb}$ at the surface, perhaps due to enhanced dilute solid-solution formation with time [4]. Rapid $\mathrm{Zn}^{2+}$ adsorption on calcite appears to occur within 12 hours via exchange of $\mathrm{Zn}^{2+}$ and $\mathrm{ZnOH}^{+}$with surface-bound $\mathrm{Ca}^{2+}$ and formation of hydrated complex $\left(\mathrm{Zn}_{5}(\mathrm{OH})_{6}\left(\mathrm{CO}_{3}\right)_{2}\right)$ being stabilized on calcite surface by chemical forces and incorporated in calcite structure by recrystallization [3, 24]. $\mathrm{Cd}^{2+}$ is adsorbed on calcite preferably than $\mathrm{Zn}^{2+}$ by forming a phase behaving as a surface precipitate [3]. $\mathrm{Cd}^{2+}$ is rapidly and reversibly adsorbed and diffused in calcite surface within 24 hours and slowly and less reversibly during the next 7 days, due to solid solution formation [25]. Taking into account that dolomite consists of layers of carbonate separated by alternating layers of calcium and magnesium ions [14], its performance in competitive solution, being similar to that of calcite, could be explained.

However, the above mentioned adsorption order of the elements from a competitive solution on calcite, as resulting from references, differentiates from the adsorption capacity of the materials. In particular, the adsorption capacity in a competitive solution for limestone follows the order $\mathrm{Cu}>\mathrm{Zn}>\mathrm{Cd}>\mathrm{Pb}$, for dolomite the order $\mathrm{Cu}>\mathrm{Zn}>\mathrm{Pb}>\mathrm{Cd}$ and for marbles the order $\mathrm{Cu}>\mathrm{Pb}>\mathrm{Zn}>\mathrm{Cd}$. $\mathrm{Zn}$ seems to be more preferred than $\mathrm{Pb}$ and $\mathrm{Cd}$, in contrast to references. However, this could be attributed to the different initial concentrations (100 mg/L Zn, $5 \mathrm{mg} / \mathrm{L} \mathrm{Pb}, 5 \mathrm{mg} / \mathrm{L} \mathrm{Cd}$ ), leading to a higher $\mathrm{Zn}$ adsorption capacity.

A significant difference observed in $\mathrm{Cd}$ and $\mathrm{Zn}$ adsorption from a competitive solution on limestone and its marble could be attributed to the adsorption mechanism of each element and the specific characteristics of each material. In particular, the higher porosity and greater pore volume of limestone, as it results from Table 5, favours the solid-state diffusion of $\mathrm{Cd}$ in its structure, which is its main adsorption mechanism $[16,25]$. On the other hand, $\mathrm{Zn}$ is sorbed on carbonate minerals by both ion exchange and precipitation [12, 24]. Therefore, the higher CEC of limestone could partially explain the higher $\mathrm{Zn}$ adsorption on it.

Another encouraging result is that leaching of the elements adsorbed on the rock surface is very low rising up to $4 \%$, which constitutes an extra benefit for their utilisation as base material of a landfill.

Finally, the application of fixed bed conditions has led to satisfying potentially toxic element adsorption. In comparison to batch experiments, almost total adsorption of the elements is achieved in all cases, attributed to the available contact time. Even if such a comparison is not 
suggested, however it could constitute a first estimation of rocks' behaviour in real conditions, in case they are utilised as landfill base.

In conclusion, the behaviour of mineral tailings, deriving from limestone and its marble, dolomite and its marble, in potentially toxic element adsorption $(\mathrm{Cd}, \mathrm{Cu}, \mathrm{Pb}$, $\mathrm{Zn}$ ) investigated in the present study, seems to be encouraging for their potential utilisation in an environmental application.

\section{References}

[1] Gu X., Evans L.J., Surface complexation modeling of Cd(II), $\mathrm{Cu}(\mathrm{II}), \mathrm{Ni}(\mathrm{II}), \mathrm{Pb}(\mathrm{II})$ and $\mathrm{Zn}(\mathrm{II})$ adsorption onto kaolinite. Geochim. Cosmochim. Ac., 72, 267-276, 2008

[2] Temman M., Paquette J., Vali H., Mn and $\mathrm{Zn}$ incorporation into calcite as a function of chloride aqueous concentration. Geochim. Cosmochim. Ac., 64(14), 2417-2430, 2000

[3] Zachara J.M., Cowan C.E., Resch C.T., Sorption of divalent metals on calcite. Geochim. Cosmochim. Ac., 55, 1549-1562, 1991

[4] Rouff A.A., Reeder R.J., Fisher N.S., Pb (II) sorption with calcite: a radiotracer study. Aquat. Geochem., 8, 203-228, 2002

[5] Rouff A.A., Elzinga E.J., Reeder R.J., X-ray Absorption Spectroscopic Evidence for the Formation of $\mathrm{Pb}$ (II) Inner-Sphere Adsorption Complexes and Precipitates at the Calcite-Water Interface. Environ. Sci. Technol., 38, 1700-1707, 2004

[6] Godelitsas A., Astilleros J.M., Hallam K., Harissopoulos S., Putnis A., Interaction of calcium carbonates with lead in aqueous solutions. Environ. Sci. Technol., 37, 3351-3360, 2003

[7] Freij S.J., Godelitsas A., Putnis A., Crystal growth and dissolution process at the calcite-water interface in the presence of zinc ions. J. Cryst. Growth, 273, 535-545, 2005

[8] Aziz H.A., Adlan M.N., Ariffin K.S., Heavy metals (Cd, Pb, Zn, Ni, $\mathrm{Cu}$ and $\mathrm{Cr}(\mathrm{III})$ ) removal from water in Malaysia: Post treatment by high quality limestone. Bioresource Technol., 99, 1578-1583, 2008

[9] Stipp S.L., Hochella Jr. M.F., Parks G.A., Leckie J.O., $\mathrm{Cd}^{2+}$ uptake by calcite, solid-state diffusion, and the formation of solidsolution: Interface processes observed with near-surface sensitive techniques (XPS, LEED, and AES). Geochim. Cosmochim. Ac., 56, 1941-1954, 1992

[10] Chada V.G.R., Hausner D.B., Stongin D.R., Rouff A.A., Reeder R.J. Divalent $\mathrm{Cd}$ and $\mathrm{Pb}$ uptake on calcite $\{1014\}$ cleavage faces: $\mathrm{An}$ XPS and AFM study. J. Colloid Interf. Sci., 288, 350-360, 2005

[11] Wang Y., Reardon E.J., A siderite/limestone reactor to remove arsenic and cadmium from wastewaters. Appl. Geochem., 16, 1241-1249, 2001
[12] García-Sánchez A., Álvarez-Ayuso E., Sorption of Zn, Cd and Cr on calcite. Application to purification of industrial wastewaters. Miner. Eng., 15, 539-547, 2002

[13] Kocaoba S., Comparison of Amberlite IR 120 and dolomite's performances for removal of heavy metals. J. Hazard. Mater., 147, 488-496, 2007

[14] Pehlivan E., Özkan A.M., Dinç S., Parlayici Ş., Adsorption of $\mathrm{Cu}^{2+}$ and $\mathrm{Pb}^{2+}$ ion on dolomite powder. J. Hazard. Mater., 167, 10441049, 2009

[15] Irani M., Amjadib M., Mousaviana M.A.,Comparative study of lead sorption onto natural perlite, dolomite and diatomite.Chem. Eng. J., 178, 317-323, 2011

[16] Godelitsas A., Kokkoris M., Misaelides P., Investigation of the interaction of Greek dolomitic marble with metal aqueous solutions using Rutherford backscattering and X-ray photoelectron spectroscopy. J. Radioanal. Nucl. Chem., 272(2), 339-344, 2007

[17] Litinas N., New requirements for aggregates in construction Experience from application of CE marking in Greece. In: Proceedings of the $1^{\text {st }}$ Hellenic Conference of Construction Materials and Elements, Technical Chamber of Greece, Athens, 2008

[18] EPA Test Method 9081, Cation-exchange capacity of soils (sodium acetate)

[19] Farmaki S., Vorrisi E., Karakasi O., Moutsatsou A., Utilization of dolomite mining wastes. In: Proceedings of the $3^{\text {rd }}$ Hellenic Conference for the utilization of industrial by-products in construction area, Thessaloniki, 2012, 142

[20] EN 14405, Characterisation of waste - Leaching behaviour test - Up-flow percolation test (under specified conditions)

[21] EN 12457-2, Characterisation of waste - Leaching - Compliance test for leaching of granular waste materials and sludges - Part 2: One stage batch test at a liquid to solid ratio to $10 \mathrm{~L} / \mathrm{kg}$ for materials with high solid content and with particle size below 4 $\mathrm{mm}$ (without or with size reduction)

[22] Parsiegla K.I., Katz J.L., Calcite growth inhibition by copper(II) I. Effect of supersaturation. J. Cryst. Growth, 200, 213-226, 1999

[23] Parsiegla K.I., Katz J.L., Calcite growth inhibition by copper(II) II. Effect of solution composition. J. Cryst. Growth, 213, 368-380, 2000

[24] Zachara J.M., Kittrick J.A., Harsh J.B., The mechanism of $\mathrm{Zn}^{2+}$ adsorption on calcite. Geochim. Cosmochim. Ac., 52, 2281-2291, 1988

[25] Davis J.A., Fuller C.C., Cook A.D., A model for trace metal sorption processes at the calcite surface: Adsorption of $\mathrm{Cd}^{2+}$ and subsequent solid solution formation. Geochim. Cosmochim. Ac., 51, 1477-1490, 1987

[26] Shannon R.D., Revised effective ionic radii and systematic studies of interatomic distances in halides and chalcogenides. Acta Crystallogr. A, 32, 751-767, 1976

[27] Al-Degs Y.S., El-Barghouthi M.I., Issa A.A., Khraisheh M.A., Walker G.M., Sorption of $\mathrm{Zn}(\mathrm{II}), \mathrm{Pb}(\mathrm{II})$, and $\mathrm{Co}(\mathrm{II})$ using natural sorbents: Equilibrium and kinetic studies. Water Res., 40, 26452658, 2006 